\title{
Intrinsic water-use efficiency of temperate seminatural grassland has increased since 1857: an analysis of carbon isotope discrimination of herbage from the Park Grass Experiment
}

\author{
IRIS H. KÖHLER*, PAULR. POULTON†, KARL AUERSWALD* and HANS SCHNYDER* \\ ${ }^{*}$ Lehrstuhl für Grünlandlehre, Technische Universität München, Am Hochanger 1, 85350 Freising, Germany, †Rothamsted \\ Research, Harpenden, Herts AL5 2JQ, UK
}

\begin{abstract}
A 150-year-long record of intrinsic water-use efficiency $\left(W_{i}\right)$ was derived from communitylevel carbon isotope discrimination $\left({ }^{13} \Delta\right)$ in the herbage of the unfertilized, unlimed control treatment (plot 3) of the Park Grass Experiment at Rothamsted (England) between 1857 and $2007 .{ }^{13} \Delta$ during spring growth (first cut harvested in June) averaged $21.0 \%$ ( $\pm 0.5 \%$ SD) and has not shown a long-term trend $(P=0.5)$ since $1857 .{ }^{13} \Delta$ of summer/autumn growth (second cut harvested between September and November) increased from $21.3 \%$ to $22.0 \%$ o $(P<0.001)$ between 1875 and 2007. $W_{\mathrm{i}}$ during spring growth has therefore increased by $33 \%$ since the beginning of the experiment, and $W_{i}$ of summer/autumn growth has increased by $18 \%$. The variation in ${ }^{13} \Delta$ was mainly related to weather conditions. Plant available soil water explained $51 \%$ and $40 \%$ of the variation in spring growth ${ }^{13} \Delta$ and summer/autumn growth ${ }^{13} \Delta$, respectively. In the 1857-2007 period yields have not increased, suggesting that communitylevel photosynthesis has not increased either. Therefore, the increased $W_{i}$ probably resulted from a decreased stomatal conductance. Vapour pressure deficit (VPD) during spring growth (March-June) has not changed since 1915, meaning that instantaneous water-use efficiency $\left(W_{t}\right)$ in spring time has increased and transpiration has probably decreased, provided that leaf temperature followed air temperature. Conversely, VPD in the months between the first and second cut has increased by $0.07 \mathrm{kPa}$ since 1915, offsetting the effect of increased $W_{\mathrm{i}}$ on $W_{\mathrm{t}}$ during summer and early autumn. Our results suggest that vegetation has adjusted physiologically to elevated $\mathrm{CO}_{2}$ by decreasing stomatal conductance in this nutrient-limited grassland.

Keywords: C-13, $\mathrm{C}_{3}$ grassland, climate change, $\mathrm{CO}_{2}$, herbage, long-term trend, transpiration, water-use efficiency
\end{abstract}

Received 19 May 2009 and accepted 13 August 2009

\section{Introduction}

Terrestrial ecosystems play an important role in the global carbon and water cycle. For the prediction of future climate change, it is necessary to understand how ecosystems respond to rising $\mathrm{CO}_{2}$ concentrations. Multiyear free-air $\mathrm{CO}_{2}$ enrichment (FACE) experiments with elevated $\mathrm{CO}_{2}$ (Ainsworth \& Rogers, 2007) indicate that $\mathrm{C}_{3}$ grasses decrease stomatal conductance by over $30 \%$ and increase light-saturated $\mathrm{CO}_{2}$ uptake by over $30 \%$ when growing under elevated $\left(567 \mu \mathrm{mol} \mathrm{mol}^{-1}\right.$, average of all studies) as compared with ambient $\mathrm{CO}_{2}$ concentrations $\left(366 \mu \mathrm{mol} \mathrm{mol}^{-1}\right.$, average of all studies).

Correspondence: Hans Schnyder, tel. + 49816171 5165, fax + 49816171 3243, e-mail: schnyder@wzw.tum.de
Accordingly, one would expect that the water-use efficiency of grasslands has also increased during the $\mathrm{CO}_{2}$ increase of the Anthropocene. But, this has not been verified in detail. Results from short-term experiments show the complexity of grassland responses to rising $\mathrm{CO}_{2}$ and their interactions with other environmental parameters: Shaw et al. (2002) showed that elevated $\mathrm{CO}_{2}$ suppressed the response of net primary production to increased temperature, precipitation and nitrogen availability in a California annual grassland. An increase of net primary production under elevated $\mathrm{CO}_{2}$ was only observed when other environmental parameters remained unchanged. For an alpine grassland in Switzerland, Körner et al. (1997) found low responsiveness to elevated $\mathrm{CO}_{2}$ and concluded that this ecosystem was 
already carbon saturated. In Lolium perenne L. swards, Schneider et al. (2004) showed that the responsiveness to elevated $\mathrm{CO}_{2}$ was greater at high than at low nitrogen availability. However, as acclimation responses and feedback mechanisms may occur in the long term, it is difficult to extrapolate from the relatively short-term responses of FACE experiments to long-term ecosystem responses.

Retrospective analysis of carbon isotope discrimination $\left({ }^{13} \Delta\right)$ is one way to assess the effect of $\mathrm{CO}_{2}$ on the biological coupling of carbon and water cycles over past decades and even centuries. According to the linear form of the Farquhar carbon isotope discrimination model, ${ }^{13} \Delta$ depends on the relationship between assimilation $(A)$ and stomatal conductance $\left(g_{\mathrm{s}}\right)$ which determine the ratio of intercellular $\left(c_{\mathrm{i}}\right)$ to atmospheric $\left(c_{\mathrm{a}}\right)$ $\mathrm{CO}_{2}$ concentration $\left(c_{\mathrm{i}} / c_{\mathrm{a}}\right)$

$$
{ }^{13} \Delta=a+(b-a) \frac{c_{\mathrm{i}}}{c_{\mathrm{a}}},
$$

with $a$ denoting the fractionation that occurs during diffusion of $\mathrm{CO}_{2}$ in air (4.4\%o) and $b$ the net fractionation due to carboxylation (27\%) (Farquhar et al., 1989). Estimates of ${ }^{13} \Delta$ are obtained from the carbon isotope composition of plant material $\left(\delta^{13} \mathrm{C}_{\mathrm{p}}\right)$ and the atmosphere $\left(\delta^{13} \mathrm{C}_{\mathrm{a}}\right)$

$$
{ }^{13} \Delta=\frac{\delta^{13} \mathrm{C}_{\mathrm{a}}-\delta^{13} \mathrm{C}_{\mathrm{p}}}{1+\delta^{13} \mathrm{C}_{\mathrm{p}}} .
$$

(Farquhar et al., 1989).

The relationship between $A$ and $g_{\mathrm{s}}$ is termed leaf-level 'intrinsic' water-use efficiency $\left(W_{\mathrm{i}}\right)$ (Ehleringer et al., 1993) and given by

$$
W_{\mathrm{i}}=\frac{A}{g_{\mathrm{s}}}=\frac{c_{\mathrm{a}}-c_{\mathrm{i}}}{1.6}=\frac{c_{\mathrm{a}}\left(1-\frac{c_{\mathrm{i}}}{c_{\mathrm{a}}}\right)}{1.6},
$$

where 1.6 stands for the ratio of the diffusivities of water vapour and $\mathrm{CO}_{2}$ in air. $W_{\mathrm{i}}$ is directly relevant to the comparison of water-use efficiencies among genotypes or species growing together in the field in the same environment. As is evident from Eqn (3), $W_{i}$ can be estimated directly from knowledge of ${ }^{13} \Delta$ [see Eqn (1)] and $c_{a}$, but it does not include the effect of the leafto-air difference in the mole fraction of water vapour [ $v$, see Eqn (9)] on plant transpiration. The effect of $v$ is accounted for by the 'instantaneous' water-use efficiency $\left(W_{t}\right)$, which is defined as the ratio of $A$ to transpiration $(E)$ of leaves (Farquhar et al., 1989)

$$
W_{\mathrm{t}}=\frac{A}{E}=\frac{c_{\mathrm{a}}-c_{\mathrm{i}}}{1.6 v}=\frac{c_{\mathrm{a}}\left(1-\frac{c_{\mathrm{i}}}{c_{\mathrm{a}}}\right)}{1.6 v} .
$$

Thus, ${ }^{13} \Delta$ and $W_{\mathrm{i}}$ [Eqn (3)] can be used to assess longterm trends in the balance between carbon gain and intrinsic (or potential) water loss of plants, whereas estimates of $W_{t}$ [Eqn (4)] also require chronologies of $v$ to estimate (actual) instantaneous leaf-level water-use efficiency.

To date, long-term isotope studies on the response of $W_{\mathrm{i}}$ to rising atmospheric $\mathrm{CO}_{2}$ concentrations and climate change were mainly done with trees, whose woody tissue and year rings provide convenient archives of stable carbon isotopes. Conversely, long-term series of ${ }^{13} \Delta$ from herbaceous plants are rare and have been analysed in only a few studies (Peñuelas \& Azcón-Bieto, 1992; Zhao et al., 2001; Pedicino et al., 2002). The response of plants to rising $\mathrm{CO}_{2}$ concentrations can be analysed in terms of three scenarios: (i) constant $c_{\mathrm{i}} / c_{\mathrm{a}}$, (ii) constant $c_{\mathrm{i}}$, or (iii) constant $c_{\mathrm{a}}-c_{\mathrm{i}}$, as discussed by Saurer et al. (2004). Trees did not show identical responses to rising $\mathrm{CO}_{2}$ concentrations in terms of $c_{\mathrm{i}} / c_{\mathrm{a}}$ which remained constant, increased or decreased. However, $W_{\mathrm{i}}$ increased in most studies (Bert et al., 1997; Duquesnay et al., 1998; Feng, 1999; Arneth et al., 2002; Saurer et al., 2004). This could result from decreasing stomatal conductance or increasing photosynthesis. Changes of assimilation might modify carbon storage in grassland soils, whereas changes in stomatal conductance and concurrent effects on evapotranspiration could influence water relations from the plant to the ecosystem and global scale. Decreasing stomatal conductance leads to warmer and drier air near the earth's surface (Betts et al., 2000) and increases run-off (Betts et al., 2007). It is unknown how grassland has responded to rising $\mathrm{CO}_{2}$ concentration in the long-term and whether results from FACE experiments can be extrapolated to (semi)natural grassland ecosystems. Our aim was to assess the long-term response of grassland vegetation to rising $\mathrm{CO}_{2}$ concentrations by analysing $\delta^{13} \mathrm{C}$, ${ }^{13} \Delta, W_{\mathrm{i}}$, and $W_{\mathrm{t}}$, using archived vegetation samples from the Park Grass Experiment at Rothamsted, England.

The Park Grass Experiment is the world's oldest longterm ecological experiment and an almost perfect resource for stable isotope analysis: it offers the unique possibility of analysing archived herbage samples from temperate, seminatural grassland, dating back to 1857 . The experiment was started in 1856 to test the effect of different amounts and combinations of inorganic fertilizers and organic manure on hay yield. We analysed samples from an unfertilized, unlimed treatment (plot 3). We chose this 'control plot' for our study, because its botanical composition, with regard to the proportion of grasses, legumes and forbs, has been in equilibrium for many years (Silvertown et al., 2006). Thus, we minimized any influence of changing botanical composition on the community-level $\delta^{13} \mathrm{C}$ signal. Weather records (rainfall, temperature, sunshine, and wind data) were available for the experimental site from the electronic 
Rothamsted Archive (eRA, 2008a). This made it possible to analyse both the long-term response to rising $\mathrm{CO}_{2}$ concentrations and the short-term reaction of community-level $\delta^{13} \mathrm{C}$ and derived parameters to year-to-year variation of weather conditions.

Our aims were to:

(1) determine the long-term trends of carbon isotope composition $\left(\delta^{13} \mathrm{C}\right)$, carbon isotope discrimination $\left({ }^{13} \Delta\right)$ and of intrinsic water-use efficiency $\left(W_{\mathrm{i}}\right)$ and instantaneous water-use efficiency $\left(W_{t}\right)$,

(2) assess the influence of interannually changing weather conditions on carbon isotope discrimination $\left({ }^{13} \Delta\right)$ and

(3) examine which environmental or meteorological parameter best predicts ${ }^{13} \Delta$ in a seminatural grassland plant community.

\section{Materials and methods}

\section{The Park Grass Experiment}

The Park Grass Experiment was started in 1856 at the Rothamsted agricultural research station, located approximately $40 \mathrm{~km}$ north of London in Hertfordshire, England $\left(0^{\circ} 21^{\prime}\right.$ West, $51^{\circ} 49^{\prime}$ North, $128 \mathrm{~m}$ height above sea level). About 2.8 ha of old grassland were divided into 20 plots which received different fertilizer and manure treatments. The herbage was cut and made into hay, usually in mid-June. For the first 19 years of the experiment the regrowth was often grazed by sheep but, since 1875 , a second cut has been taken, usually between late September and early November. Until 1960, samples of hay were taken from the material dried in situ. Since 1960 strips have been cut with a forage harvester and vegetation samples were taken directly from the fresh material and dried afterwards. However, the herbage on the rest of the plot was made into hay as before. The second cut has usually been cut and carted green. Samples from all plots have been dried and stored in the Rothamsted Archive since the beginning of the experiment (Silvertown et al., 2006).

We analysed samples from one of the unfertilized, unlimed control plots (plot 3). In 1903, most plots were divided in two and lime was applied to one half every 4 years. The unlimed part of plot 3 was then named 3U. In 1965 the limed and unlimed subplots were divided again and three of the four subplots received chalk to achieve a $\mathrm{pH}$ of 5, 6, and 7, respectively. One subplot remained unlimed and this was named $3 \mathrm{~d}$ (note: the whole experiment received a small amount of lime in the 1880s).

Studies of the botanical composition of the Park Grass plots have been made for 73 spring cut harvests by separating harvested samples into guilds (grasses, legumes, other forbs) or even into single species to determine their percentage contribution to total harvested biomass. Since the beginning of the experiment, grasses have been dominant (mean/minimum/maximum: $60 / 29 / 91 \%$ ) on plot 3 and on the unlimed subplots $3 \mathrm{U}$ and $3 \mathrm{~d}$, followed by other forbs (33/9/67\%) while legumes contributed only a small percentage $(7 / 0 / 15 \%)$. At the species level, the dominating grasses were Agrostis capillaris L. and Festuca rubra L., common forbs were Centaurea nigra L., Leontodon hispidus L. and Plantago lanceolata L. Data are available from the electronic Rothamsted Archive (eRA, 2008a).

The soil is a moderately well-drained silty clay loam overlying clay-with-flints and chalk. It is classified as stagnogleyic palaeo-argillic brown earth by the Soil Survey of England and Wales or as Aquic Paleudalf according to USDA classification (Avery \& Catt, 1995). The water-holding capacity (or maximum plant available soil water, $\mathrm{PAW}_{\text {capacity }}$ ) of the soil has not been measured directly, but was inferred from measurements on similar soils. It was $135 \mathrm{~mm}$.

\section{Sample preparation and isotope analysis}

Representative subsamples of $2-3 \mathrm{~g}$ were taken from the archived samples of plot 3 (until 1902), half plot $3 \mathrm{U}$ (after 1903), and quarter plot 3d (after 1965). The first and the second cut were sampled and analysed separately. The subsamples were dried at $40^{\circ} \mathrm{C}$ for $48 \mathrm{~h}$, ball milled to a homogenous fine powder and dried again at $60^{\circ} \mathrm{C}$ for $24 \mathrm{~h}$. Aliquots of $0.7 \pm 0.05 \mathrm{mg}$ were weighed into tin cups (IVA Analysentechnik e.K., Meerbusch, Germany) and combusted in an elemental analyzer (NA 1110; Carlo Erba, Milan, Italy) interfaced (Conflo III; Finnigan MAT, Bremen, Germany) with an isotope ratio mass spectrometer (Delta Plus; Finnigan MAT). Carbon isotope data are presented in the conventional form as $\delta^{13} \mathrm{C}$, where $\delta^{13} \mathrm{C}=\left[\left(R_{\text {sample }} / R_{\text {standard }}\right)-1\right]$, with $R$ the ${ }^{13} \mathrm{C} /{ }^{12} \mathrm{C}$ ratio in the sample or standard (V-PDB). Each sample was measured against a laboratory working standard $\mathrm{CO}_{2}$ gas, which was previously calibrated against a secondary isotope standard (IAEA-CH6 for ${ }^{13} \mathrm{C}$, accuracy of calibration $\pm 0.06 \% \mathrm{SD}$ ). After every 10th sample a solid internal laboratory standard (SILS) with similar $\mathrm{C} / \mathrm{N}$ ratio as the respective sample material (fine ground wheat flour) was run as a control. The SILS were previously calibrated against an international standard (IAEA-CH6). The precision for sample repeats was better than $0.1 \%$ (SD of 57 SILS replications).

We tested if the change of the harvesting method in 1960 had an effect on the $\delta^{13} \mathrm{C}$ of the vegetation samples. This analysis was possible as samples for the first cut in 1992, 1993, and 1994 had been obtained with both 
harvesting methods. The comparison revealed that $\delta^{13} \mathrm{C}$ of the samples taken from hay was less negative by $0.18 \%$ ( $\pm 0.06 \mathrm{SD})$. This phenomenon was probably related to larger losses of leaf material during hay making before 1960. To correct for this, we subtracted $0.18 \%$ from the $\delta^{13} \mathrm{C}$ of the first cut samples collected before 1960 .

\section{Atmospheric $\mathrm{CO}_{2}$ concentration and isotope composition}

Atmospheric carbon isotope data $\left(\delta^{13} \mathrm{C}_{\mathrm{a}}\right)$ and $\mathrm{CO}_{2}$ concentrations were estimated following an approach by Wittmer et al. (2008). Data were taken from ice-core studies (Friedli et al., 1986; Francey et al., 1999; for $\delta^{13} C_{a}$ data before 1978 and for $\mathrm{CO}_{2}$ concentration data before 1959) and from atmospheric monitoring (Mauna Loa: Keeling \& Whorf, 2005; Shetland Islands: Allison et al., 2003; Ocean Station M, Storhofdi Vestmannaeyjar Island, Mace Head: NOAA ESRL, 2007). Two cubic functions were fitted to the $\delta^{13} \mathrm{C}_{\mathrm{a}}$ data to estimate mean annual values. The first model $\left(\delta^{13} \mathrm{C}_{\mathrm{a}}=-26.5169\right.$. $\left.t^{3}+136.238 \cdot t^{2}-234.2816 \cdot t+128.56\right) \quad$ provided estimates for the 1850-1958 period and the second model $\left(\delta^{13} \mathrm{C}_{\mathrm{a}}=10693.7615 \cdot t^{3}-63649.6643 \cdot t^{2}+126245.672\right.$. $t-83450.9684)$ for the 1959-2007 period, where $t$ is the sampling year/1000. The cubic fit for the 1959-2007 period was forced to pass through the 1958 value estimated with the first model for the 1850-1958 period. The root mean squared error for the overall $\delta^{13} \mathrm{C}_{\mathrm{a}}$ model was $0.05 \%$. The $\delta^{13} \mathrm{C}_{\mathrm{a}}$ decreased from $-6.5 \%$ in 1857 to $-8.4 \%$ in 2007. For calculation of mean $\delta^{13} C_{a}$ during the two growing periods a seasonal correction factor was applied: analysis of monthly measured $\delta^{13} \mathrm{C}_{\mathrm{a}}$ (Allison et al., 2003; NOAA ESRL, 2007) showed that, compared with the yearly average, $\delta^{13} C_{a}$ from March to June was more negative by $0.2 \%$ and $\delta^{13} \mathrm{C}_{\mathrm{a}}$ from July to November was more positive by $0.3 \%$.

A quadratic function was fitted to the $\mathrm{CO}_{2}$ concentration data for the period from 1850 to 1958, and a cubic function for the period after 1959. The root mean squared error for the overall $\mathrm{CO}_{2}$ concentration model was $0.6 \mu \mathrm{mol} \mathrm{mol}^{-1} \cdot \mathrm{CO}_{2}$ concentration increased from $287 \mu \mathrm{mol} \mathrm{mol}^{-1}$ in 1857 to $383 \mu \mathrm{mol} \mathrm{mol}^{-1}$ in 2007 . Analysis of monthly measured $\mathrm{CO}_{2}$ concentration data (Allison et al., 2003; NOAA ESRL, 2007) showed that $\mathrm{CO}_{2}$ concentration, compared with the yearly average, was higher during March to June $\left(+3.4 \mu \mathrm{mol} \mathrm{mol}^{-1}\right)$ and lower during July to November $\left(-4.7 \mu \mathrm{mol} \mathrm{mol}^{-1}\right)$.

\section{Climatic data}

Daily precipitation at Rothamsted has been measured since 1853 with a large rain gauge (' $1 / 1000$ th acre

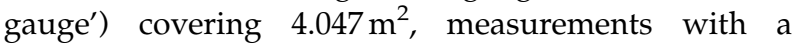

Meteorological Office standard rain gauge are available since 1948. Rainfall data from both gauges correlated closely $\left(R^{2}=0.96\right)$ but values from the $1 / 1000$ th acre gauge are on average $7 \%$ higher. We used data from the $1 / 1000$ th gauge, as it presents the longest continuous measurement. Where daily measurements were missing for calculation of PAW in the 1947-2007 period, they were estimated from the values measured with the standard gauge. Where this was not possible, a mean value of $3.6 \mathrm{~mm} \mathrm{day}^{-1}$ rainfall was assumed (this was the case for 425 days after 1 January 1947, that is $2 \%$ of the data).

Temperature at Rothamsted has been measured daily since 1878 . Daily mean temperature $\left(\bar{T}_{\text {Day }}\right)$ was calculated according to Allen et al. (1998)

$$
\bar{T}_{\text {Day }}=\left(T_{\text {Max }}+T_{\text {Min }}\right) / 2,
$$

with $T_{\text {Min }}$ the measured daily minimum and $T_{\mathrm{Max}}$ the measured daily maximum temperature.

The saturation vapour pressure $(e)$ is related to air temperature $(T)$ and can be derived using the equation given by Allen et al. (1998)

$$
e(T)=0.6108 e^{\left(\frac{17277}{T+237.3}\right)} .
$$

Daily mean saturation vapour pressure $\left(e_{\mathrm{s}}\right)$ was calculated as

$$
e_{\mathrm{s}}=\left(\frac{e\left(T_{\max }\right)+e\left(T_{\min }\right)}{2}\right),
$$

and actual vapour pressure $\left(e_{\mathrm{a}}\right)$ was calculated as the saturation vapour pressure at the dew point temperature $\left(T_{\text {Dew }}\right)$

$$
e_{\mathrm{a}}=e\left(T_{\text {Dew }}\right) .
$$

Dew point temperature $\left(T_{\text {Dew }}\right)$ was calculated from measured wet and dry bulb temperature (available since 1915) with the equation given in the electronic Rothamsted Archive (eRA, 2008b). The atmospheric vapour pressure deficit (VPD) was calculated as the difference of actual and saturation vapour pressure.

For calculation of $W_{t}$, the leaf-to-air difference in the mole fraction of water vapour is used, which is the VPD between the air and intercellular gas spaces of the leaf divided by total atmospheric pressure.

$$
v=\frac{e_{\mathrm{s}}-e_{\mathrm{a}}}{p_{\text {total }}},
$$

where $p_{\text {total }}$ is the total pressure of the atmosphere $(99.8 \mathrm{kPa}$ at $128 \mathrm{~m}$ height above sea level). It was assumed that leaf temperature was equal to mean air temperature.

Potential evapotranspiration (PET) was calculated using the FAO Penman-Monteith equation for a grass reference crop (Allen et al., 1998). This equation 
incorporates the effect of crop morpho-physiological characteristics on PET by using fixed coefficients for bulk surface resistance and aerodynamic resistance. PAW was calculated according to Schnyder et al. (2006)

$$
\mathrm{PAW}_{i}=\mathrm{PAW}_{i-1}+\mathrm{P}_{i}-\mathrm{AET}_{i}
$$

with PAW $_{i-1}$ the modelled PAW of the previous day, $\mathrm{P}_{i}$ the precipitation on day $i$, and $\mathrm{AET}_{i}$ the modelled actual evapotranspiration on day $i$. $\mathrm{AET}_{i}$ equalled $\mathrm{PET}_{i}$ as long as $\mathrm{PAW}_{i} / \mathrm{PAW}_{\text {capacity }}>0.3$. Otherwise $\mathrm{AET}_{i}$ was calculated as

$$
\mathrm{AET}=\frac{\mathrm{PET}}{0.3} \times \frac{\mathrm{PAW}_{i}}{\mathrm{PAW}_{\text {capacity }}}
$$

All weather parameters necessary for the calculation of PET, AET, and PAW were available for the 1947-2006 period or were derived from other parameters according to Allen et al. (1998): windspeed was calculated from windrun measurements, solar radiation was estimated from the measured duration of bright sunshine. Modelling was started on the 15th of February in 1947 when $\mathrm{PAW}_{i}$ was set to $135 \mathrm{~mm}$ (the PAW capacity), as the soil was most likely saturated with water at that time of the year.

\section{Results}

\section{Local trends in climatic conditions}

Mean annual rainfall was $735 \mathrm{~mm}( \pm 120 \mathrm{~mm}$ SD) between 1857 and 2007, and no significant long-term trend was observed. There was seasonality in the record, with highest rainfall in autumn $(210 \pm 68 \mathrm{~mm})$ and lowest in spring $(156 \pm 50 \mathrm{~mm})$, which is also reflected in other precipitation records from England and Wales (Wood, 2004). There was a peak in rainfall around 1875 . Mean daily precipitation during spring (Fig. 1a) and summer/autumn (Fig. 1f) growth did not show significant trends.

Mean annual temperature has increased significantly since the beginning of the recording in 1878. But after 1990 the increase was more pronounced. Mean annual temperature in the $1878-1989$ period was $9.1^{\circ} \mathrm{C}$, but in the 1990-2007 period it was $10.2^{\circ} \mathrm{C}$. Mean temperatures during spring (Fig. 1b) and summer/autumn (Fig. 1g) growth have increased significantly $(P<0.0001)$.

No trend was observed in the VPD during spring growth (Fig. 1c, $P=0.4$ ). In contrast, the VPD in the summer/autumn period has increased by approximately $0.07 \mathrm{kPa}$ since 1915 (Fig. $1 \mathrm{~h}, P<0.01$ ). Thus, the annual sum of PET has increased significantly by

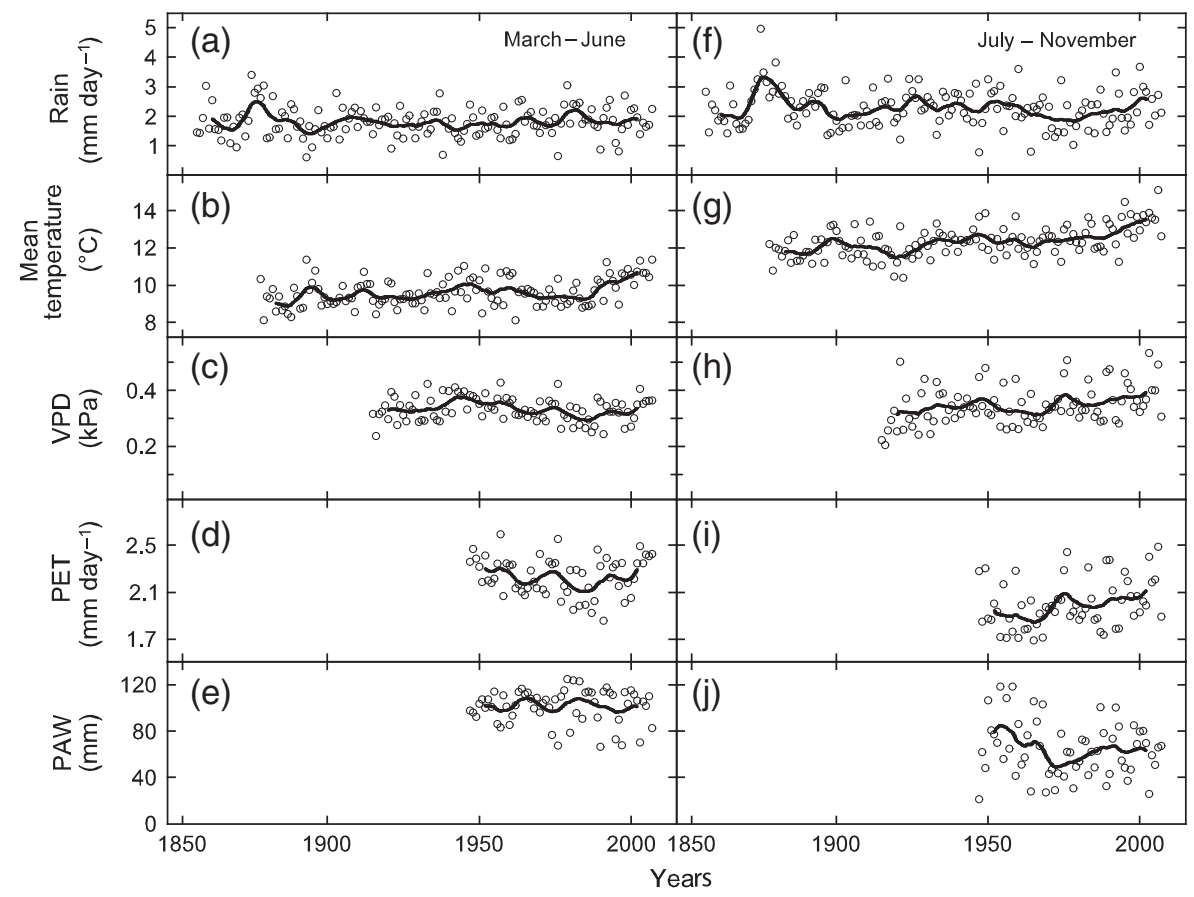

Fig. 1 Climate data $(\mathrm{O})$ averaged over the growth season of the spring growth (March-June, left column) and the summer/autumn growth (July-November, right column). (a) and (f) mean daily rainfall, (b) and (g) mean temperature, (c) and (h) mean vapour pressure deficit (VPD), (d) and (i) mean potential evapotranspiration (PET), and (e) and (j) mean plant available soil water (PAW). Lines are the 11years weighted moving averages. For analysis of trends best-fit linear regressions were calculated. Significant trends were observed for temperature which increased in both seasons $(P<0.0001)$ and for VPD and PET which increased in the summer/autumn season $(P<0.01$ and $P<0.05$ ). 
$0.66 \mathrm{~mm} \mathrm{yr}^{-1}(P<0.05)$ from $603 \mathrm{~mm}$ in 1947 to $643 \mathrm{~mm}$ in 2007, but PET during spring growth showed no significant trend (Fig. 1d). Accordingly, no long-term change in PAW was observed in spring (Fig. 1e) and average PAW in June was $67 \mathrm{~mm}$ ( $\pm 33 \mathrm{~mm}$ SD). Mean daily PET during summer/autumn growth increased significantly from 1.8 to $2.0 \mathrm{~mm} \mathrm{day}^{-1}$ from 1947 to 2007 (Fig. 1i, $P<0.05$ ). However, PAW averaged from July to November did not show a significant trend during this period (Fig. 1j). Mean PAW in July was $45 \mathrm{~mm}( \pm 29 \mathrm{~mm}$ $\mathrm{SD})$ and increased to $110 \mathrm{~mm}( \pm 33 \mathrm{~mm}$ SD) in November. Trends were evaluated using best-fit linear regression.

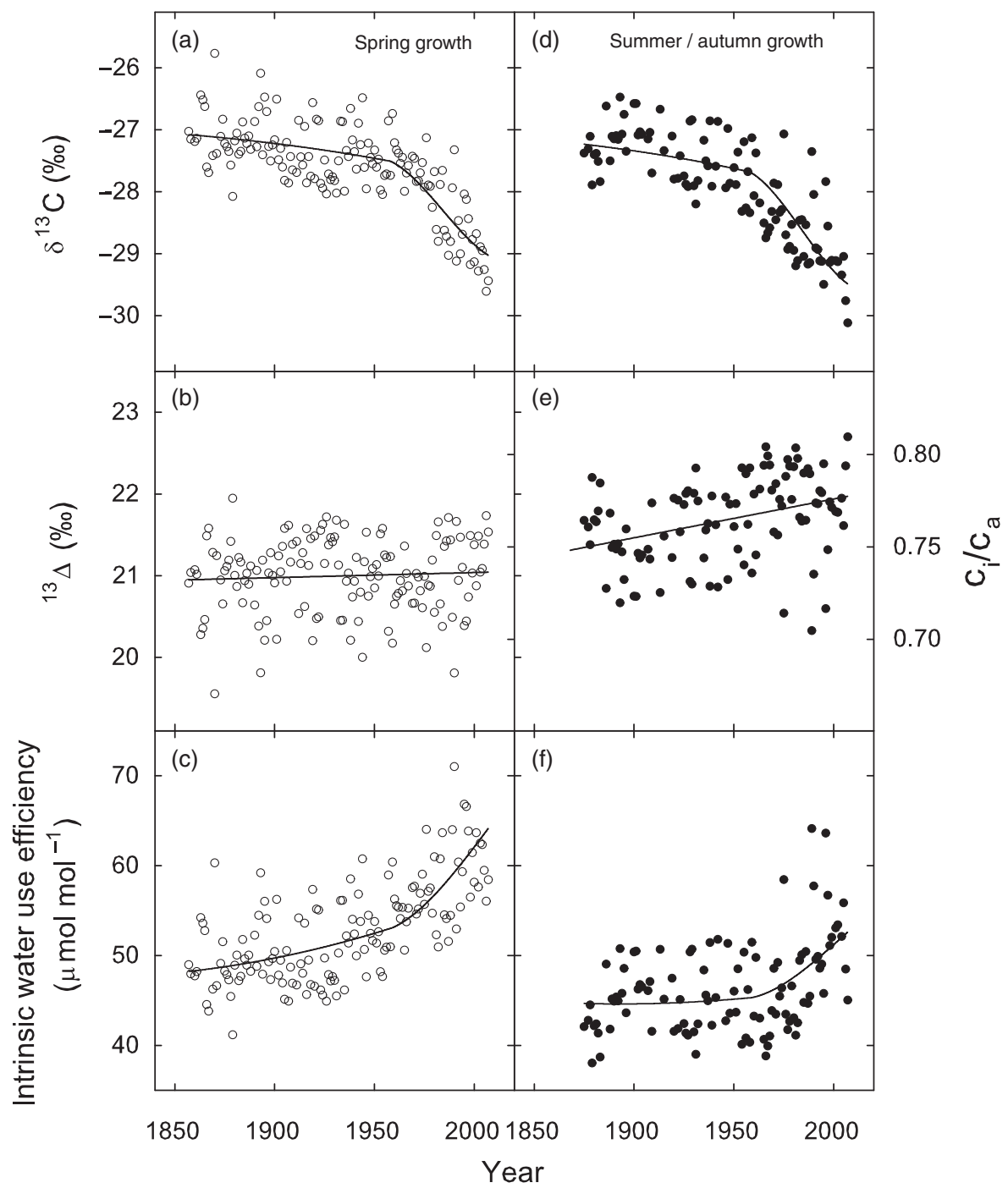

Fig. 2 Trends in carbon isotope composition $\left(\delta^{13} \mathrm{C}\right)$, carbon isotope discrimination $\left({ }^{13} \Delta\right)$, the ratio of leaf internal to atmospheric $\mathrm{CO}_{2}$ concentration $\left(c_{\mathrm{i}} / c_{\mathrm{a}}\right)$ and intrinsic water-use efficiency $\left(W_{\mathrm{i}}\right)$. Graphs on the left side $(\mathrm{a}-\mathrm{c})$ show the trends for spring growth $(\mathrm{O})$ since 1857 , graphs on the right side $(\mathrm{d}-\mathrm{f})$ show the trends for summer/autumn growth $(\bullet)$ since 1875 . Lines in (a) and (d) give the $\delta^{13} \mathrm{C}_{\mathrm{p}}$ values modelled from atmospheric $\delta^{13} \mathrm{C}$, using the linear relationship between $\delta^{13} \mathrm{C}_{\text {plant }}(y)$ and $\delta^{13} \mathrm{C}_{\mathrm{atm}}(x)$ (spring: $y=1.05 x-20.1, R^{2}=0.63$, $P<0.0001$; summer/autumn: $\left.y=1.25 x-19.4, R^{2}=0.67, P<0.0001\right) .{ }^{13} \Delta$ was calculated from Eqn (2), lines in (b) and (e) are best-fit linear regressions, where ${ }^{13} \Delta$ of summer/autumn growth is significant against year $\left({ }^{13} \Delta=0.0048\right.$ year $\left.+12.4, P<0.001\right)$, while ${ }^{13} \Delta$ of spring growth was not $\left({ }^{13} \Delta=0.0006\right.$ year $\left.+19.8, P=0.5\right)$. $W_{\mathrm{i}}$ was calculated from Eqn (3): The line in (c) gives the modelled $W_{\mathrm{i}}$ values using Eqn (3) and assuming a constant mean $c_{\mathrm{i}} / c_{\mathrm{a}}$ ratio of 0.73 for spring growth. The line in (f) gives the modelled $W_{\mathrm{i}}$ values calculated from Eqn (3) with modelled $c_{\mathrm{i}} / c_{\mathrm{a}}$ derived from the linear regression of $c_{\mathrm{i}} / c_{\mathrm{a}}$ against year $\left(c_{\mathrm{i}} / c_{\mathrm{a}}=0.00021\right.$ year $\left.+0.355, P<0.001\right)$. $W_{\mathrm{i}}$ increased in proportion to $c_{\mathrm{a}}$ from 48 to $64 \mu \mathrm{mol} \mathrm{mol}^{-1}$ ( $+33 \%$ ) for the first cut and from 45 to $53 \mu \mathrm{mol} \mathrm{mol}^{-1}$ (+ 18\%) for the second cut. 
Trends in $\delta^{13} \mathrm{C}$ of vegetation

The $\delta^{13} \mathrm{C}$ of the herbage $\left(\delta^{13} \mathrm{C}_{\mathrm{p}}\right)$ decreased over the last 150 years, as $\operatorname{did} \delta^{13} \mathrm{C}_{\mathrm{a}}$, with a more rapid decrease after 1960 (Fig. 2a and d). The linear relationship between $\delta^{13} \mathrm{C}_{\mathrm{p}}$ and $\delta^{13} \mathrm{C}_{\mathrm{a}}$ (data not shown) was used to model $\delta^{13} \mathrm{C}_{\mathrm{p}}$ without the interannual fluctuations from 1857 to 2007: thus $\delta^{13} \mathrm{C}_{\mathrm{p}}$ of the first cut decreased by $1.9 \%$ (from approximately $-27.1 \%$ at $290 \mu \mathrm{mol} \mathrm{mol}^{-1}$ to $-29.0 \%$ at $386 \mu \mathrm{mol} \mathrm{mol}^{-1}$, Fig. 2a), while $\delta^{13} \mathrm{C}_{\mathrm{p}}$ of the second cut decreased by $2.3 \%$ (from approximately $-27.2 \%$ at $286 \mu \mathrm{mol} \mathrm{mol}^{-1}$ to $-29.5 \%$ at $378 \mu \mathrm{mol} \mathrm{mol}^{-1}$, Fig. $2 \mathrm{~d}$ ) between 1875 and 2007.

Long-term trends in ${ }^{13} \Delta, \mathrm{c}_{i} / \mathrm{c}_{a}, \mathrm{c}_{i}$, and intrinsic water-use efficiency

There was no systematic long-term trend of ${ }^{13} \Delta$ in the last 150 years for the first cut ( $P=0.5$ ) (Fig. $2 b)$ and the long-term mean ${ }^{13} \Delta$ was $21.0 \%$ ( $\pm 0.5 \%$ SD). ${ }^{13} \Delta$ of the second cut increased by $0.7 \%$ from $21.3 \%$ in 1875 to $22.0 \%$ in 2007 (Fig. 2e, $P<0.001$ ). As ${ }^{13} \Delta$ and the $c_{\mathrm{i}} / c_{\mathrm{a}}$ ratio are linearly related [Eqn (1)], the $c_{\mathrm{i}} / c_{\mathrm{a}}$ ratio remained constant for the first cut $(0.73 \pm 0.02 \mathrm{SD})$ and increased slightly for the second cut from 0.75 to 0.78 (1875-2007). Accordingly, the intercellular $\mathrm{CO}_{2}$ concentration increased with atmospheric $\mathrm{CO}_{2}$, rising from approximately 213 to $284 \mu \mathrm{mol} \mathrm{mol}^{-1}$ for the first cut (1857-2007), and from approximately 214 to $294 \mu \mathrm{mol} \mathrm{mol}^{-1}$ for the second cut (1875-2007). In the same way $W_{\mathrm{i}}$ increased from 48 to $64 \mu \mathrm{mol} \mathrm{mol}^{-1}$ for spring growth (Fig. 2c) and from 45 to $53 \mu \mathrm{mol} \mathrm{mol}^{-1}$ for the summer/autumn growth (Fig. 2f).
As the VPD remained constant from March to June in the long-term, $W_{t}$ of spring growth increased in proportion to $W_{\mathrm{i}}$, that is from 14.8 to $19.6 \mathrm{mmol} \mathrm{mol}^{-1}$ in the 1915-2007 period (Fig. 3a). In contrast, the long-term increase of VPD in the months preceding the second cut compensated for the effect of increasing $W_{i}$ so that $W_{t}$ of the summer/autumn growth remained approximately constant at $13.9 \mathrm{mmol} \mathrm{mol}^{-1}$ in the $1915-2007$ period (Fig. 3b).

\section{Correlation of ${ }^{13} \Delta$ with environmental parameters}

${ }^{13} \Delta$ was correlated with environmental parameters (Table 1) to identify potential causes for the substantial interannual variation of ${ }^{13} \Delta$. PAW could only be estimated for the 1947-2007 period. Rainfall was used for the analysis of the whole period since 1857. Mean PAW in June explained $51 \%(P<0.0001)$ of the variation in ${ }^{13} \Delta$ of the spring growth in the 1947-2007 period (Fig. 4a). Mean daily rainfall from March to June explained 33\% of the variation in ${ }^{13} \Delta$ for the $1857-2007$ period $(P<0.0001)$. Mean PAW from July to September explained $40 \%(P<0.0001)$ of the variation in ${ }^{13} \Delta$ of the summer/autumn growth for the 1947-2007 period (Fig. $4 b)$, but no correlation was found with mean daily rainfall (1875-2007).

When the correlation between ${ }^{13} \Delta$ and atmospheric $\mathrm{CO}_{2}$ concentration was analysed separately in dry and wet years (determined by mean daily rainfall), no significant correlation in either dry or wet years was found for the 1857-2007 period for the first cut, nor for the 1875-2007 period for the second cut.

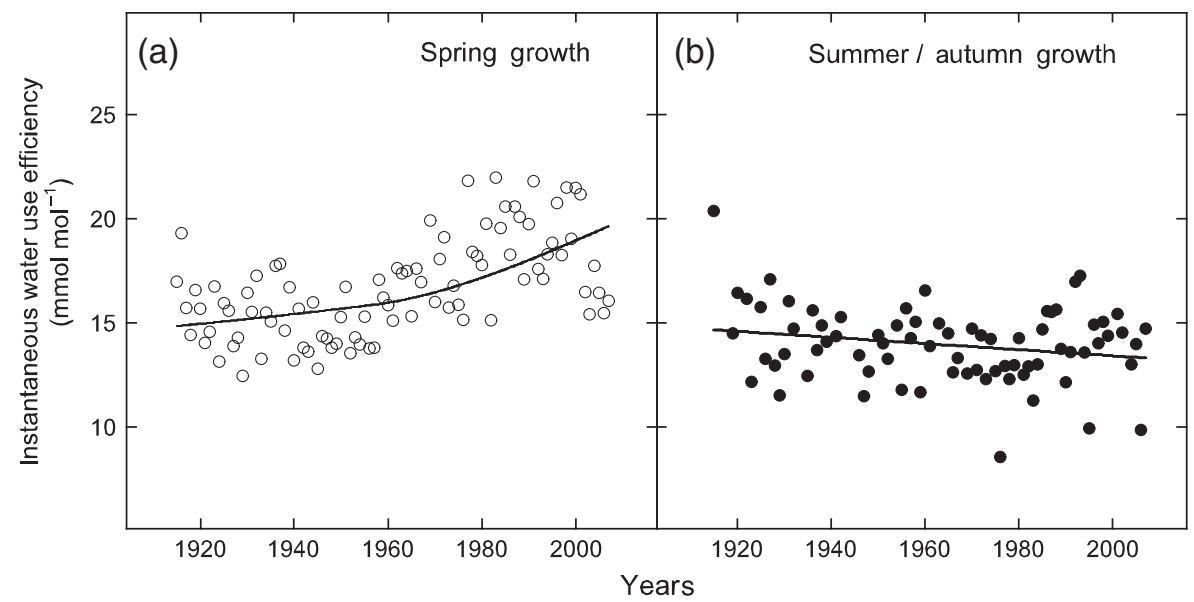

Fig. 3 Trends in instantaneous water-use efficiency $\left(W_{t}\right)$ for (a) spring (O) and (b) summer/autumn growth (•) since 1915. $W_{t}$ was calculated according to Eqn (4) from intrinsic water-use efficiency and the leaf-to-air difference in the mole fraction of water vapour $[v$, Eqn (9)]. The line in (a) gives the modelled $W_{t}$ values using modelled $W_{i}$ and $v$, (mean March-June) estimated from linear regression against year $(v=-0.0014$ year +6.15$)$. $W_{\mathrm{t}}$ of the spring growth increased from 14.8 to $19.6 \mathrm{mmol} \mathrm{mol}^{-1}(+33 \%)$. The line in (b) is the bestfit linear regression for $W_{t}$ of summer/autumn growth against year $\left(W_{t}=-0.0147\right.$ year $\left.+42.8586, P=0.07\right)$. $W_{t}$ of summer/autumn growth remained constant at about $13.9 \mathrm{mmol} \mathrm{mol}^{-1}$. 
Wet spring was defined as mean daily rainfall in March-June $>2 \mathrm{~mm}$ and dry spring was defined as mean daily rainfall in March-June $<1.5 \mathrm{~mm}$. Wet autumn was defined as mean daily rainfall in September $>3 \mathrm{~mm}$ and dry autumn was defined as mean daily rainfall in September $<1 \mathrm{~mm}$.

\section{Discussion}

The near-constancy of ${ }^{13} \Delta$-trends: decreasing stomatal conductance or increasing assimilation?

Carbon isotope discrimination $\left({ }^{13} \Delta\right)$ of the unfertilized control plot of the Park Grass Experiment did not show a long-term trend for the first cut (1857-2007) but it increased slightly, although significantly, for the second cut (1875-2007). These responses meant that the $c_{\mathrm{i}} / c_{\mathrm{a}}$ ratio was near-constant in the first cut and increased slightly in the second cut, provided that the relationship between ${ }^{13} \Delta$ and the $c_{\mathrm{i}} / c_{\mathrm{a}}$ ratio as predicted by Eqn (1) was accurate. It has been noted that Eqn (1) is a simplification, as it supposes that mesophyll conductance $\left(g_{\mathrm{m}}\right)$ is unlimited (Farquhar et al., 1989; Seibt et al., 2007). However, $g_{\mathrm{m}}$ is finite and variable (Flexas et al., 2008), complicating to some extent the inference of ${ }^{13} \Delta$ on the $c_{\mathrm{i}} / c_{\mathrm{a}}$ ratio (Seibt et al., 2007). Yet, $g_{\mathrm{s}}$ and $g_{\mathrm{m}}$ are generally correlated, increasing and decreasing in parallel across different plant species (Loreto et al., 1992), genotypes (Lauteri et al., 1997) and stress conditions (Centritto et al., 2003; Flexas et al., 2004). Further, in the present study the species composition, with regard to the proportion of grasses, legumes and forbs, was approximately stable over time (Silvertown et al., 2006), minimizing opportunities for changes of $g_{\mathrm{m}}$ (and related effects on $W_{\mathrm{i}}$ ) which might result from changes in species composition and related effects on photosynthetic traits. Therefore, we feel that the relationship between ${ }^{13} \Delta$ and $c_{\mathrm{i}} / c_{\mathrm{a}}$ ratio, as presented here, was actually quite stable.

The relative constancy of $c_{\mathrm{i}} / c_{\mathrm{a}}$ ratio (and therefore ${ }^{13} \Delta$ ) during rising $\mathrm{CO}_{2}$ concentration implies that stomatal conductance has decreased and/or assimilation has increased [Eqns (1) and (3)]. Yields on plot 3 had not increased by 1992 (Jenkinson et al., 1994) nor thereafter (data not shown). As photosynthesis and yield are related, and yield did not change, we should expect that stomatal conductance decreased in the face of increasing $\mathrm{CO}_{2}$. Lack of a yield- and photosynthesisresponse was probably due to nutrient-limitation of this unfertilized plot (Reich et al., 2006). Nitrogen-limitation on plot 3 is due to higher $\mathrm{N}$ removal as compared with $\mathrm{N}$ input: The total sum of nitrogen removal in the form of harvested biomass for both cuts in the 1876-2001 period was estimated to be $4020 \mathrm{~kg} \mathrm{Nha}^{-1}$, as opposed 


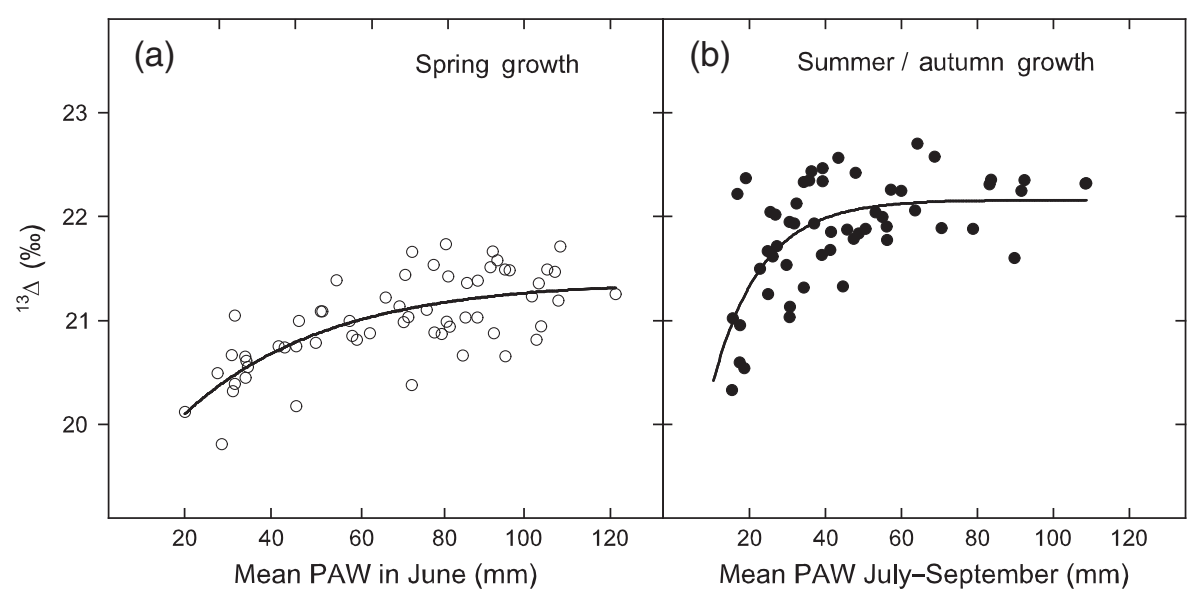

Fig. $4{ }^{13} \mathrm{C}$ discrimination of (a) spring and (b) summer/autumn growth as related to mean plant available soil water PAW in (a) June and (b) July-September. ${ }^{13} \Delta$ showed a saturation response, approaching $21.4 \%$ for spring growth $\left[{ }^{13} \Delta=19.6671+1.7156(1-\exp (-0.0266\right.$ PAW $\left.\left.{ }_{\text {June }}\right), R^{2}=0.51\right]$ and $22.2 \%$ for summer/autumn growth $\left[{ }^{13} \Delta=18.1779+3.9817\left(1-\exp \left(-0.0779\right.\right.\right.$ PAW $\left.\left.\left.{ }_{\text {July-Sept }}\right)\right), R^{2}=0.40\right]$.

to $3460 \mathrm{~kg} \mathrm{Nha}^{-1}$ estimated atmospheric nitrogen deposition as calculated according to Goulding et al. (1998) for the same period. Currently, total annual $\mathrm{N}$ offtake through biomass is ca. $40 \mathrm{~kg} \mathrm{Nha}^{-1}$ and atmospheric $\mathrm{N}$ input is ca. $35 \mathrm{~kg} \mathrm{Nha}^{-1}$.

Also, in one 10 years-long FACE study in a temperate climate, elevated $\mathrm{CO}_{2}$ had no effect on herbage yield when nitrogen was added at a moderate rate, whereas addition of nitrogen fertilizer at a high rate sustained a strong enhancement of aboveground biomass production of L. perenne L. swards (Schneider et al., 2004). Such responses are the rule, although they are not always observed (Reich et al., 2006). A stronger acclimation response of photosynthesis under nitrogen limitation was also observed repeatedly (Ainsworth \& Rogers, 2007). Together, these features all support the view that the long-term constancy of ${ }^{13} \Delta$, and $c_{\mathrm{i}} / c_{\mathrm{a}}$ ratio, in the present nutrient-limited grassland was mainly achieved via a decrease of stomatal conductance. Moreover, they demonstrate that this response was sustained over a period of more than one century.

Intrinsic water-use efficiency $\left(\mathrm{W}_{i}\right)$ vs. instantaneous water-use efficiency $\left(\mathrm{W}_{t}\right)$

The ${ }^{13} \Delta$ and $c_{\mathrm{a}}$ data showed that $W_{\mathrm{i}}$ increased by $33 \%$ in the first cut and by $18 \%$ in the second cut, indicating that $W_{\mathrm{i}}$ of this temperate grassland system has adjusted physiologically to the rising $\mathrm{CO}_{2}$ concentration of the last century. Interestingly, the response was similar to that observed in long-term isotope studies on trees (Bert et al., 1997; Duquesnay et al., 1998; Feng, 1999; Saurer et al., 2004) suggesting that there may be no fundamental difference between (temperate and northern latitude) forests and temperate grasslands in the response of intrinsic water-use efficiency to increasing $\mathrm{CO}_{2}$.

The increased intrinsic water-use efficiency of the first cut was probably translated into the same increase of $W_{\mathrm{t}}$, because spring-time VPD (March-June) did not change. In total, both increased by approximately $30 \%$ (1915-2007). If we assume that assimilation has remained unchanged (as above) leaf-level transpiration must have decreased accordingly. Furthermore, if the allometry of aboveground biomass and leaf area did not change, then system-scale transpiration must have decreased in the same way, increasing the likelihood of groundwater recharge and runoff losses of water in spring time. Conversely, the increase of $W_{\mathrm{i}}$ during summer/autumn growth $(+18 \%)$ was probably completely offset by the increased VPD. Thus $W_{t}$ remained unchanged. Again, if we argue in the same way as above, then transpiration probably did not decrease in the summer/autumn period. Thus, system-scale transpiration would have decreased in spring but not in summer/autumn, changing the seasonal cycle of transpiration.

However, these conclusions are based on the assumption that leaf temperature followed air temperature. Decreasing stomatal conductance and therefore decreasing transpiration could lead to increasing leaf temperature, thus increasing the VPD between leaf intercellular spaces and the atmosphere. We estimated for the spring growth that leaf temperature must have increased by $1.3^{\circ} \mathrm{C}$ above ambient to offset the increase in $W_{\mathrm{t}}$.

Absolute values of $W_{t}$ were relatively high, as the mean leaf-to-air difference in the mole fraction of water vapour at the study site was comparatively low (mean 
value for the 1915-2007 period from March to June: $3.3 \pm 0.4 \mathrm{mmol} \mathrm{mol}^{-1}$ and for July-November: $\left.3.5 \pm 0.7 \mathrm{mmol} \mathrm{mol}^{-1}\right)$.

\section{Correlation of ${ }^{13} \Delta$ with environmental parameters}

Interannual and intraannual variations of ${ }^{13} \Delta$ were most strongly correlated with PAW. Such a close relationship between PAW and community-level ${ }^{13} \Delta$ has been observed before (Schnyder et al., 2006), but has not been analysed in long series of climatic observations in grassland. Correlations with other weather factors, such as precipitation and VPD, were also evident and agreed with those observed by others (Korol et al., 1999; Hemming et al., 2005; Schulze et al., 2006). However, relationships of ${ }^{13} \Delta$ with precipitation and VPD were weaker and less consistent than those with PAW. So, it does seem that the closer relationship between PAW and ${ }^{13} \Delta$ was due to the more integrative nature of this parameter, which accounted for the effects of evaporative demand and precipitation on canopy hydraulics. Certainly, the present observation of a strong relationship between PAW and ${ }^{13} \Delta$ calls for a careful interpretation of $\mathrm{CO}_{2}$ effects on ${ }^{13} \Delta$, as these could result (indirectly) from the antitranspirant effect of $\mathrm{CO}_{2}$ on PAW.

\section{Conclusion}

This work presents a long-term series of communitylevel carbon isotope composition of a temperate nutrientlimited grassland. We showed that community-level ${ }^{13} \Delta$ was constant or increased slightly during the increase in the concentration of atmospheric $\mathrm{CO}_{2}$ over the last 150 years. This suggested that $W_{\mathrm{i}}$ increased substantially during spring and summer/autumn growth, consistent with observations on trees. However, the effect of $\mathrm{CO}_{2}$ on $W_{\mathrm{t}}$ was strongly modified by VPD. Spring-time VPD did not change since 1915, so that $W_{\mathrm{i}}$ and $W_{\mathrm{t}}$ increased in the same way ( $+30 \%$ in both cases). In contrast, VPD during summer/autumn growth increased after 1915, completely negating the effect of increased $W_{\mathrm{i}}$ on $W_{\mathrm{t}}$. However, increases in leaf temperature might have offset some of the antitranspirant effect of elevated $\mathrm{CO}_{2}$. The dataset revealed significant intra- and interannual variation in ${ }^{13} \Delta$ which was closely related to variation in PAW.

\section{Acknowledgements}

We thank the Lawes Agricultural Trust for access to the archived samples. Rothamsted Research is an institute of the UK Biotechnology and Biological Sciences Research Council.

\section{References}

Ainsworth EA, Rogers A (2007) The response of photosynthesis and stomatal conductance to rising $\left[\mathrm{CO}_{2}\right]$ : mechanisms and environmental interactions. Plant, Cell, and Environment, 30, 258-270.

Allen RG, Pereira LS, Raes D, Smith M (1998) Crop Evapotranspiration Guidelines for computing Crop Water Requirements - FAO Irrigation and Drainage Paper 56. Food and Agricultural Organization of the United Nations, Rome.

Allison CE, Francey RJ, Krummel PB (2003) $\delta^{13} \mathrm{C}$ in $\mathrm{CO}_{2}$ from sites in the CSIRO atmospheric research GASLAB air sampling network (April 2003 version). In: Trends: A Compendium of Data on Global Change. Carbon Dioxide Information Analysis Center, Oak Ridge National Laboratory, US Department of Energy, Oak Ridge, TN, USA.

Arneth A, Lloyd J, Šantrůčková H, Bird M et al. (2002) Response of central Siberian Scots pine to soil water deficit and long-term trends in atmospheric $\mathrm{CO}_{2}$ concentration. Global Biogeochemical Cycles, 16, 1005, doi: 10.1029/2000GB001374.

Avery BW, Catt JA (1995) The Soil at Rothamsted. Lawes Agricultural Trust, Harpenden, UK.

Bert D, Leavitt SW, Dupouey JL (1997) Variations of wood $\delta^{13} \mathrm{C}$ and water-use efficiency of Abies alba during the last century. Ecology, 78, 1588-1596.

Betts RA, Boucher O, Collins M et al. (2007) Projected increase in continental runoff due to plant responses to increasing carbon dioxide. Nature, 448, 1037-1041.

Betts RA, Cox PM, Woodward FI (2000) Simulated responses of potential vegetation to doubled- $\mathrm{CO}_{2}$ climate change and feedbacks on near-surface temperature. Global Ecology and Biogeography, 9, 171-180.

Centritto M, Loreto F, Chartzoulakis K (2003) The use of low $\left[\mathrm{CO}_{2}\right]$ to estimate diffusional and non-diffusional limitations of photosynthetic capacity of salt-stressed olive saplings. Plant, Cell, and Environment, 26, 585-594.

Duquesnay A, Bréda N, Stievenard M, Dupouey JL (1998) Changes of tree-ring $\delta^{13} \mathrm{C}$ and water-use efficiency of beech (Fagus sylvatica L.) in north-eastern France during the past century. Plant, Cell, and Environment, 21, 565-572.

Ehleringer JA, Hall AE, Farquhar GD), eds (1993) Stable Isotopes and Plant Carbon-Water Relations. Academic Press, London.

eRA (2008a) Rothamsted Electronic Archive. Available at http://www. era.rothamsted.ac.uk (accessed 23 February 2008).

eRA (2008b) Rothamsted Electronic Archive, Calculation of Derived Variables. Available at http://www.era.rothamsted.ac.uk/metdata 4.html\#SEC53 (accessed 23 February 2008).

Farquhar GD, Ehleringer JR, Hubick KT (1989) Carbon isotope discrimination and photosynthesis. Annual Review of Plant Physiology and Plant Molecular Biology, 40, 503-537.

Feng XH (1999) Trends in intrinsic water-use efficiency of natural trees for the past 100-200 years: a response to atmospheric $\mathrm{CO}_{2}$ concentration. Geochimica et Cosmochimica Acta, 63, 1891-1903.

Flexas J, Bota J, Loreto F, Cornic G, Sharkey TD (2004) Diffusive and metabolic limitations to photosynthesis under drought and salinity in $\mathrm{C}_{3}$ plants. Plant Biology, 6, 269-279.

Flexas J, Ribas-Carbo M, Diaz-Espejo A, Galmés J, Medrano H (2008) Mesophyll conductance to $\mathrm{CO}_{2}$ : current knowledge and future prospects. Plant, Cell, and Environment, 31, 602-621.

Francey RJ, Allison CE, Etheridge DM et al. (1999) A 1000-year high precision record of $\delta^{13} \mathrm{C}$ in atmospheric $\mathrm{CO}_{2}$. Tellus, 51B, 170-193.

Friedli H, Lötscher H, Oeschger H, Siegenthaler U, Stauffer B (1986) Ice core record of the ${ }^{13} \mathrm{C} /{ }^{12} \mathrm{C}$ ratio of atmospheric $\mathrm{CO}_{2}$ in the past two centuries. Nature, 324, 237-238.

Goulding KWT, Bailey NJ, Bradbury NJ et al. (1998) Nitrogen deposition and its contribution to nitrogen cycling and associated soil processes. New Phytologist, 139, 49-58. 
Hemming D, Yakir D, Ambus P et al. (2005) Pan-European $\delta^{13} \mathrm{C}$ values of air and organic matter from forest ecosystems. Global Change Biology, 11, 1065-1093.

Jenkinson DS, Potts JM, Perry JN, Barnett V, Coleman K, Johnston AE (1994) Trends in herbage yields over the last century on the Rothamsted Long-term Continuous Hay Experiment. Journal of Agricultural Science, 122, 365-374.

Keeling CD, Whorf TP (2005) Atmospheric $\mathrm{CO}_{2}$ records from sites in the SIO air sampling network. Trends: A Compendium of Data on Global Change. Carbon Dioxide Information Analysis Center, Oak Ridge National Laboratory, US Department of Energy, Oak Ridge, TN, USA.

Körner C, Diemer M, Schappi B, Niklaus P, Arnone J (1997) The responses of alpine grassland to four seasons of $\mathrm{CO}_{2}$ enrichment: a synthesis. Acta Oecologica, 18, 165-175.

Korol RL, Kirschbaum MUF, Farquhar GD, Jeffreys M (1999) Effects of water status and soil fertility on the C-isotope signature in Pinus radiata. Tree Physiology, 19, 551-562.

Lauteri M, Scartazza A, Guido MC, Brugnoli E (1997) Genetic variation in photosynthetic capacity, carbon isotope discrimination and mesophyll conductance in provenances of Castanea sativa adapted to different environments. Functional Ecology, 11, 675-683.

Loreto F, Harley PC, Di Marco G, Sharkey TD (1992) Estimation of mesophyll conductance to $\mathrm{CO}_{2}$ flux by three different methods. Plant Physiology, 98, 1437-1443.

NOAA ESRL (2007) Global Monitoring Division Data Archive. Available at ftp://ftp.cmdl.noaa.gov/ccg/co2c13/flask/month (accessed 11 August 2007).

Pedicino LC, Leavitt SW, Betancourt JL, Van de Water PK (2002) Historical variations in $\delta^{13} \mathrm{C}_{L E A F}$ of herbarium specimens in the southwestern US. Western North American Naturalist, 62, 348-359.

Peñuelas J, Azcón-Bieto J (1992) Changes in leaf $\Delta^{13} \mathrm{C}$ of herbarium plant species during the last 3 centuries of $\mathrm{CO}_{2}$ increase. Plant, Cell, and Environment, 15, 485-489.
Reich PB, Hungate BA, Luo YQ (2006) Carbon-nitrogen interactions in terrestrial ecosystems in response to rising atmospheric carbon dioxide. Annual Review of Ecology Evolution and Systematics, 37, 611-636.

Saurer M, Siegwolf RTW, Schweingruber FH (2004) Carbon isotope discrimination indicates improving water-use efficiency of trees in northern Eurasia over the last 100 years. Global Change Biology, 19, 2109-2120.

Schneider MK, Lüscher A, Richter $\mathrm{M}$ et al. (2004) Ten years of free-air $\mathrm{CO}_{2}$ enrichment altered the mobilization of $\mathrm{N}$ from soil in Lolium perenne $\mathrm{L}$. swards. Global Change Biology, 10, 1377-1388.

Schnyder H, Schwertl M, Auerswald K, Schäufele R (2006) Hair of grazing cattle provides an integrated measure of the effects of site conditions and interannual weather variability on $\delta^{13} \mathrm{C}$ of temperate humid grassland. Global Change Biology, 12, 1315-1329.

Schulze ED, Turner NC, Nicolle D, Schumacher J (2006) Leaf and wood carbon isotope ratios, specific leaf areas and wood growth of Eucalyptus species across a rainfall gradient in Australia. Tree Physiology, 26, 479-492.

Seibt U, Rajabi A, Griffiths H, Berry J (2007) Carbon isotopes and water use efficiency: sense and sensitivity. Oecologia, 155, 441-454.

Shaw MR, Zavaleta ES, Chiariello NR, Cleland EE, Mooney HA, Field CB (2002) Grassland responses to global environmental changes suppressed by elevated $\mathrm{CO}_{2}$. Science, 298, 1987-1990.

Silvertown J, Poulton P, Johnston E, Edwards G, Heard M, Biss PM (2006) The Park Grass Experiment 1856-2006: its contribution to ecology. Journal of Ecology, 94, 801-814.

Wittmer MHOM, Auerswald K, Tungalag R, Bai YF, Schäufele R, Schnyder $H$ (2008) Carbon isotope discrimination of $C_{3}$ vegetation in Central Asian grassland as related to long-term and short-term precipitation patterns. Biogeosciences, 5, 913-924.

Wood NLH (2004) Regional climate trends in South-West England and the North Atlantic Oscillation. Weather, 56, 39-41.

Zhao FJ, Spiro B, McGrath SP (2001) Trends in ${ }^{13} \mathrm{C} /{ }^{12} \mathrm{C}$ ratios and $\mathrm{C}$ isotope discrimination of wheat since 1845. Oecologia, 128, 336-342. 